\title{
The Use of Critical Thinking Activities through Workshops to improve EFL Learners' Speaking Skills
}

\author{
Eliana Pinza-Tapia, Vanessa Toro, \\ Karina Salcedo-Viteri and Fabian Paredes \\ Universidad Técnica Particular de Loja, Loja, Ecuador \\ https://orcid.org/0000-0002-9717-0721 \\ https://orcid.org/0000-0002-5928-4285 \\ https:// orcid.org/0000-0003-0272-3475 \\ https://orcid.org/0000-0001-9219-4284
}

\begin{abstract}
Speaking is considered to be the most complex skill to master by EFL (English as a foreign language) learners. Unfortunately, Ecuadorian students do not reach the desired speaking level. To address this issue, this mixed-method study aims at identifying the impact of critical thinking activities through workshops, in order to improve learners' speaking skills. This study was conducted at public high schools in the different provinces of Ecuador. The sample consisted of 635 students from the tenth grade of elementary school and the first and second grades of senior high school. The data-collection instruments were a pre-test, and a post-test, to find out the students' CEFR speaking level, and an observation grid to discover students' attitude and performance concerning oral communication skills. Additionally, five different workshops, based on the use of critical thinking activities were carried out. The results led us to the conclusion that critical thinking workshops have a positive impact on students' speaking skills. They allowed students to use accurate grammar, vocabulary, and to improve their fluency and pronunciation, in order to communicate their ideas orally.
\end{abstract}

Keywords: critical thinking Activities; EFL learners; speaking skill; workshops

\section{Introduction}

The educational community makes great efforts to improve students' speaking skills. These efforts are evidenced through the application of the different methods and strategies to reach successful oral communication with students. One example of the previous statement is observed in the study carried out by Vellayan et al. (2021), who conclude that Cooperative Learning allows for the 
improvement of the speaking competency in students. Unfortunately, in Ecuador, speaking is not given the attention it deserves, and teachers continue to use traditional methods that do not provide the desired results. Villafuerte (2019) claims that in Ecuadorian public institutions, the grammar-translation method is largely used during EFL classes, despite the mandate to apply up-to-date approaches, such as Content and Language Integrated Learning (CLIL), thereby making learning authentic and more meaningful.

By the same token, Met (1998), as cited in the English language curriculum of Ecuador (2016), claims that there is an increase in the quality of students' learning when they use higher order thinking skills and participate and interact more.

As stated, the development of critical thinking skills benefits students in the improvement of their speaking skills. Worrell and Profetto-McGrath (2007) explain that critical thinking provides students with tools that will allow them to communicate in a more effective way, and to decide when to use their oral skills, which should improve with practice. Also, the same author states that students who develop their critical thinking abilities are better learners; because they are able to acquire knowledge by correctly inquiring to obtain essential information. Finally, when students use critical thinking, they can analyze and conclude about what is said by others, which might later be used in their own utterances.

By the same token, critical thinking benefits from practice. by using a variety of different real-life scenarios, which entail deep thinking when making complex decisions. There are several ways that the real-world application of critical thinking is encouraged in the classroom. These ways are: homework assignments, class exercises, class debates, or tests (Bensley \& Murtagh, 2012).

Several studies have shown evidence of the relationship between critical thinking and speaking skills. In relation to this, Iman (2017) carried out a study on the use of debates to improve the students' critical thinking and speaking skills. The author ascertained that the use of this technique makes a significant improvement in critical thinking and speaking skills and concluded that there is a significant contribution of the debate to the various aspects of critical thinking.

Arfae (2019) carried out a study, which focused on investigating the impact of teaching critical thinking on EFL learners' speaking skills by applying debate, media analysis, and problem-solving. In this study, the author concluded that there is an important relationship between the development of critical thinking and EFL learners' speaking skills.

Finally, Akatsuka (2019) aimed to investigate Japanese students' perceptions that related to critical thinking (CT) attitudes and their intention to improve their speaking skills, and to discover effective CT approaches.

The author used various higher cognitive level questions for students to answer, as well as some academic presentations and discussion questions after each 
presentation. The author concluded that regardless of the students' English proficiency levels, there was a significant improvement in their speaking skills.

The present study focuses on the use of critical thinking workshops, and the impact they have on the improvement of students' speaking skills. Workshops represent an advantage in education; since they assist training students and teachers with the best academic alternatives, which involve different activities and tasks organized, in order to encourage students to think in a more critical way. This training is necessary for students to have clear ideas before communicating these orally. The findings should provide the educational community, especially teachers, with a better understanding of the most appropriate strategies to be applied in classes, in order to improve English oral communication, which should provide an alternative way to deal with the stated problem.

On this basis, this study aims to identify the impact that critical thinking activities through workshops have on learners' speaking skills. To meet this aim, the following research questions have been formulated:

- RQ1 - What is the speaking proficiency level in students from public high schools, before using critical thinking activities through workshops?

- RQ2 - What is the impact of using critical thinking activities on the speaking proficiency level in students from public high schools?

\section{The Literature Review}

\subsection{Critical Thinking Development}

According to Cottrell (2005), critical thinking is a cognitive activity that concentrates on the issue of argumentation; and it involves using the mind. Facione (2000) believed that critical thinking is a self-adjusting process that involves using cognitive skills for making judgments. Critical thinking is important in the various fields that involve communicating ideas, making decisions, analyzing, and solving problems (Lau, 2011).

Moseley et al. (2005) remarked that critical thinking is a crucial component of quality education across all age groups and disciplines. The authors also confirmed that empirical evidence demonstrates that thinking can be improved with courses that are explicitly designed to teach thinking skills, and with thinking-skill instructions. Moreover, Muhammadiyeva et al. (2020) state that critical thinking helps foreign language learners to develop speaking skills by bringing different perspectives into learning environments and classroom settings. They also mention that teachers need to select activities and tasks that promote critical thinking skills.

Regarding the teaching field, different studies have been developed to determine the impact that critical thinking has on the improvement of speaking skills. In this vein, Malmir and Shoorcheh (2012) studied the effect of critical thinking on Iranian EFL learners' speaking ability. The results showed that students who used critical thinking strategies had better results on the oral interview post-test, as opposed to the results of the pre-test. The results demonstrated that students 
who received instruction in using critical thinking strategies had better results in the oral interview post-test, as opposed to those of the pre-test. Therefore, the authors concluded that critical thinking training has a great impact on the improvement of speaking skills.

Additionally, Changwon et al. (2018) conducted a study to develop a new instructional model to enhance high school students' critical thinking. Moreover, they proposed to measure and compare the experimental group's critical thinking skills and academic achievement to those of the control group. They also aimed to measure and analyze the experimental group students' satisfaction regarding the use of the instructional model, as a learning-management tool.

The findings revealed that the instructional model is an effective tool to be used in the educational setting. Furthermore, the experimental group achieved higher scores than the control group in respect of critical thinking and academic achievement. Finally, students from the experimental group demonstrated a high level of satisfaction with the applied learning activities.

Gandimathi and Zarei (2018) investigated the use of critical thinking in English language learning. For this purpose, a qualitative method was used as an instrument to collect the data. A semi-structured interview was applied to 30 postgraduate students in Selangor. They analyzed the information, by using content analysis. As a conclusion, it was determined that critical thinking allows students to learn in a better way, and that students were able to learn better by using critical thinking; since it helped them to solve problems in learning when they used their reflective and independent thinking, which enabled the improvement of their English-language skills.

Paul (1985) stated that one of the primary objectives of schooling and education is the ability to think critically. Likewise, Malmir and Schoorcheh (2012) mentioned that those learners who are more effective in their speaking performances are much more successful and effective in school, as well as in the other areas of their lives. Regarding these statements, a study was conducted in the area of critical thinking to determine its connection with speaking skills. Ramezani et al. (2015) selected 100 English university students, in Rasht, Iran, in order to apply the IELTS Speaking test and the Lauren Starkey Critical Thinking Test. This study revealed a significant correlation coefficient between speaking performance and critical thinking; and the main result was that those students, who were recognized as critical thinkers performed better in their speaking.

Furthermore, Vahdani and Tarighat (2014) carried out a study to find the impact that critical thinking skills have on speaking proficiency. For this purpose, the authors chose a mixed-method approach; and they selected two groups of female students as the experimental and the control group. The authors concluded that creating an understanding of critical thinking could improve English proficiency. 
Consequently, it is relevant to include critical thinking activities in schools and universities. Additionally, the authors explained that teachers must have critical thinking skills, in order to be able to teach students.

Xu (2013) conducted a study on critical thinking in College English learning, with the objective to ascertain whether the students' behavior changes after the instruction in critical thinking in oral discussions, and to provide some strategies for encouraging critical-thinking ability. The participants of this study were students and teachers from three different majors. Questionnaires and interviews, self-evaluation, and the instructor's field notes were used as the data-collection tools. The author concluded that classroom instruction could facilitate the advancement of students' critical thinking skills, increase their initiatives, and improve their comprehensive ability. In relation to these strategies, the author established that self-directed learning improves students' critical thinking ability.

Finally, Kaviani and Mashhadi (2020) investigated the effectiveness of critical thinking to improve EFL learners' productive skills in an English Language Institute in the city of Babol. The IELTS intermediate speaking and writing test was applied to 80 pre-intermediate students, as the pre-test. The whole group of students was divided into four categories: two control and two experimental groups, each one with 20 students. In the two experimental groups, some critical thinking activities were used to learn speaking and writing skills. After the intervention, the same IELTS test was applied, as that in the post-test. The findings revealed that critical thinking significantly contributes to the acquisition of productive skills.

\subsection{Developing speaking skills}

Brown and Lee (2015) proposed intrinsically motivating techniques that focus on students' ultimate goals, interests, and needs. Such techniques allow students to develop competencies and to achieve autonomy as well. In this regard, some authors have researched different techniques, which could help English-speaking learners to develop their speaking skills. Muhammadiyeva, et al. (2020) highlighted that involving students in speaking activities that require the use of critical thinking skills helps students to express their thoughts orally, and also to become fluent in another language. For this purpose, these authors concluded that teachers need to select various activities that provide a positive environment for discussion.

Dewi et al. (2016) proposed communication games, in order to promote students' interaction in the classroom and to provide opportunities for them to actively participate in speaking and writing. Additionally, Harmer (2015) argued that communication games to help students to speak as quickly and fluently as possible. By the same token, Sevy-Biloon (2017) explained that using games in English-speaking classes promotes a relaxing environment that enhances communication among peers.

In line with the above information, Hernandez et. al. (2021) conducted a study to boost EFL learners' speaking skills through communication games. The findings of this study revealed that communication games are an effective way to increase 
students' self-confidence, participation, and interaction. They perform spontaneously, thereby improving their accuracy and fluency of speech, and their use of vocabulary, as well. Additionally, the use of communication games helps to overcome the students' fear of making mistakes.

It is well-known that the use of videos for educational purposes brings benefits, such as the improvement of the ability to process and retain information. In this respect, June et al. (2014) argued that the use of YouTube videos encourages students to be more expressive; and it offers the benefit of a longer attention span. The authors also suggest that YouTube videos promote students' participation and commitment; similarly, the use of these videos helps to develop their critical thinking skills. Additionally, the use of YouTube videos engages students in the teaching and learning process (Kabooha \& Elyas, 2015).

Similarly, Gunada (2017) claimed that YouTube videos can improve students' speaking skills; since they contain authentic English. The students are thereby provided with better exposure to speaking issues, such as pronunciation, structure, vocabulary, and intonation, all of which can contribute to the improvement of students' speaking, comprehension, and fluency.

Pardede (2011) suggested that applying short stories in the EFL classroom allows one to involve various other activities in the reading, listening, writing, and speaking classes. Learning activities, such as oral reading, dramatization, improvisation, roleplaying, re-enactment, and discussion, based on stories may enhance students' speaking and listening skills. Bretz (1990, as cited in Pardede, 2011) claimed that the use of short stories in the ESL/EFL classroom helps to develop students' communicative competence and critical-thinking skills. Additionally, Arias (2017) suggested that short stories allow students to understand the function of the language; thereby they can improve their use of grammar, cohesion, and coherence.

Consequently, students can be involved in group-work activities, in order to share their ideas, and to practice writing, and oral skills. The author also claims that since students acquire vocabulary and expressions, this strengthens their communication and increases their self-confidence to communicate in the spoken language.

Hismanoglu and Colak (2019) conducted a study to identify Turkish K-12 EFL teachers' views and knowledge about the use and effectiveness of drama-based speaking activities in the development of students' speaking skills. The results showed that the drama techniques K-12 EFL teachers know the most are role play, dramatization, role-changing, storytelling, phone conversations, flashback, and role cards. The drama techniques that K-12 EFL teachers use the most are role playing, dramatization, phone conversations, storytelling, role cards, and role changing. The findings also suggest that K-12 EFL teachers, who have received drama education, have higher levels of perspectives than those who have not received any drama education. 
Being conscious of research on Turkish K-12 EFL teachers' views about the use of drama to improve students' speaking skills is crucial, when seeking to set up a stress-free, non-threatening and entertaining procedure in the classroom environment. Additionally, the use of drama-based speaking activities involves students in active learning through an environment that supports the development of speaking skills (Hismanoglu \& Colak, 2019). Likewise, Kaiafa et. al., (2020) argued that educational drama is a creative approach to education that promotes autonomous learning and provides students with opportunities to express themselves freely, to develop their critical thinking skills, and to foster teamwork.

The results of researchers also show that applying storytelling allows students to better recall new vocabulary, have more opportunities to practice speaking, to develop their competence in speaking the target language, and to boost their learning (Hwang et al., 2016). These issues are supported by Zuhriyah (2017), who conducted a collaborative action research to determine whether storytelling could improve students' speaking skill in an intensive English program. The study's findings showed that the use of storytelling improves students' speaking skills because of the good progress students achieve in the speaking test. The author claimed that storytelling is useful to improve students' comprehension, fluency, vocabulary, grammar, and pronunciation, as well.

Focusing on role-play activities, Altun (2015) conducted a study to determine the impact these activities have on students' oral communication skills. The results revealed that through role-play activities, students develop their self-confidence and increase their motivation favoring the improvement of oral communicative competence.

Karsono (2014) carried out a study based on the use of pictures to improve the speaking ability of eighth grade students. The findings demonstrated that using pictures helps students to improve their speaking skills and their participation; since thereby they improve their fluency, pronunciation, and grammar. Another study was conducted by Lavalle and Briesmaster (2017) with the purpose of using strategies, such as picture descriptions to motivate students to improve their communication skills.

Eighth-grade students from a private school were considered as the participants of this study; and they demonstrated an improvement in their communication skills in terms of their pronunciation, motivation, and competence. The use of debates represents another instructional strategy that contributes significantly to the improvement of students' critical thinking and speaking skills. Snider and Schnurer (2002) consider that in-class debates promote active participation; because they give students the responsibility of comprehension. Anchalee (2015) developed a study with the purpose of investigating the effectiveness of using the debating technique to develop the English-speaking skill of 10 th -grade high school students and determining the students' perceptions on the use of debates in the classroom. The instruments used to collect the data were pre- and post-tests and a questionnaire. Considering the results obtained from the pre-test and the post- 
test, the students showed a significant improvement in their speaking competence. Regarding the students' perceptions, the results demonstrated that they are satisfied with the use of debates because these debates help them to think critically.

Another study, which focused on debates, was carried out by Zare and Othman (2015), who aimed at identifying the students' perceptions on the use of classroom debates to improve their critical thinking and oral communication ability. For this purpose, sixteen undergraduate students were randomly selected to take part in debates for nine sessions during one semester. The students' perceptions were gathered through surveys and semi-structured interviews. The results showed that students were very satisfied with the debate experience; because it helped them improve their critical thinking skills, confidence level, and speaking ability.

The authors highlight that careful attention must be paid to the debate topics; since all the students mentioned that they influence their participation and their motivation.

\section{The Method}

\subsection{The participants}

The study was conducted at public high schools in 28 cities in different provinces of Ecuador. The provinces are part of the three Ecuadorian regions: Amazon, Coast, and Highlands.

For selecting the participants, the convenient sampling method was applied. The sample consisted of 635 students, 340 females and 295 males, from the 10th grade of elementary school and $1^{\text {st }}$ and $2^{\text {nd }}$ grades of senior high schools. These learners, whose ages ranged from 14 to 16 years, belonged to different socio-economic categories. Additionally, 60 pre-service teachers and eight university teachers participated in this study. The following Table presents the demographic information regarding the selected sample.

Table 1. Demographic information of the participants

\begin{tabular}{|l|c|}
\hline Ecuadorian Region & Number of students \\
\hline Amazon Region & $\mathbf{2 0}$ \\
\hline 1st grade BGU & 10 \\
\hline 2nd grade BGU & 10 \\
\hline Coast Region & $\mathbf{1 1 1}$ \\
\hline 10mo grade EGB & 49 \\
\hline 2nd grade BGU & 62 \\
\hline Highlands Region & $\mathbf{5 0 4}$ \\
\hline 10mo grade EGB & $\mathbf{2 0 5}$ \\
\hline 1st grade BGU & $\mathbf{1 5 8}$ \\
\hline 2nd grade BGU & $\mathbf{1 4 1}$ \\
\hline General & $\mathbf{6 3 5}$ \\
\hline
\end{tabular}




\subsection{The procedures}

To carry out this study, a mixed-method research design that combines qualitative and quantitative methods was applied. The instruments (see Appendices) used to collect the data from the field research were a pre-test, a post-test, and an observation grid. The pre-test and the post-test included 24 open-ended questions used to determine the students' level of speaking ability, according to the Common European Framework of Reference for Languages (CEFR) - both before and after attending the established workshops. The observation sheet included open-ended and close-ended questions. The aim of the observation sheet was to collect information on the activities carried out during the workshops, as well as the students' performance and attitude regarding the use of different strategies to develop the students' oral communication skills.

To provide valid and reliable instruments, the pre-test and the post-test included validated questions taken from the Face2Face oral placement test from Cambridge University Press (Question banks 1 and 2). The observation grid was delivered to the English teacher's colleagues for the corresponding validation process.

This study was conducted in six months; and it involved different stages. The first one was to train pre-service teachers regarding the use of different critical thinking activities and resources, in order to help learners to improve their oral skills. This training was carried out by the eight university lecturers within a period of four weeks.

The second stage involved pre-service teachers administering the pre-test, in order to know the students' oral proficiency level, which allowed pre-service teachers and researchers to become aware of the students' weaknesses and strengths regarding their English oral communication skills. With this purpose, each pre-service teacher held a face-to-face meeting to apply the test to each student; and this took approximately 40 minutes per student. The students' answers to each question were recorded and transcribed. Then, they were registered on a mark sheet, in order to record the corresponding scores. The scores obtained in this test were used to place students, according to their oral proficiency level, which was based on the following table:

Table 2. Oral English Proficiency Levels

\begin{tabular}{|c|c|c|c|}
\hline \multicolumn{4}{|c|}{ Oral English Proficiency Levels } \\
\hline A1 & A2 & B1 & B1+ \\
\hline Beginner & Elementary & Pre-intermediate & Intermediate \\
\hline $\begin{array}{c}\text { From questions 1 to } \\
6\end{array}$ & From questions 7 to & From questions 13 to & From questions 19 to \\
& 12 & 18 & 24 \\
\hline
\end{tabular}

Once the results of the pre-test were obtained, the next stage took place. It required pre-service teachers to design five different workshop plans, as well as the corresponding materials to be used in the five workshops. These workshop plans were carefully reviewed by the university teachers, in order to ensure a highquality work. 
The workshops were carried out to help the students to improve their oral communication skills through the development of critical thinking activities. Preservice teachers were responsible for conducting these workshops. Each workshop was carried out once a week; and it focused on a specific topic and strategy. Short stories were used first as the main strategy, then educational videos, followed by games and pictures. Finally, the use of role plays was required to encourage the students to develop their critical thinking ability. During the execution of the last workshop that focused on the use of role plays, the oral production of students was recorded as a final product, which was evidence of the improvement of the students' oral performance.

At the end of the workshops, the last stage took place. It implied the application of the post-test to ascertain whether there had been any improvement in the results obtained through the pre-test. University teachers, who participated as researchers of the study, observed the execution of the workshops, in order to ensure the quality of the contents, the activities and the materials being used. Also, they took notes on the students' reactions and performance regarding the applied activities.

For the data tabulation, the number of students who maintained the same speaking proficiency level and those who had increased their level of performance was clearly established. This information was classified, according to the high school grades to which the students belonged. To carry out this tabulation process, the SPSS statistics software was used.

The analysis procedure contrasted the data from the grades, regarding the students who maintained their initial speaking proficiency level with those ones who had improved them. This information was supported by the data obtained from the observation grid. For showing the level of significance of the obtained results, the ANOVA analysis was applied.

\section{Results and the discussion thereof}

Table 3. EFL learners' speaking proficiency during the pre-test

\begin{tabular}{|l|l|l|}
\hline Speaking Proficiency Level / School grades & Number of students & Percentage \\
\hline A1 & $\mathbf{4 5 1}$ & $\mathbf{7 1 . 1}$ \\
\hline 10th grade EGB & 184 & 29.0 \\
\hline 1st grade BGU & 115 & 18.1 \\
\hline 2nd grade BGU & 152 & 24.0 \\
\hline A2 & $\mathbf{9 8}$ & $\mathbf{1 5 . 4}$ \\
\hline 10th grade EGB & 38 & 5.9 \\
\hline 1st grade BGU & 17 & 2.6 \\
\hline 2nd grade BGU & 44 & 6.9 \\
\hline B1 & $\mathbf{7 3}$ & $\mathbf{1 1 . 5}$ \\
\hline 10th grade EGB & 27 & 4.3 \\
\hline 1st grade BGU & 28 & 4.4 \\
\hline
\end{tabular}




\begin{tabular}{|l|l|l|}
\hline 2nd grade BGU & 18 & 2.8 \\
\hline B1+ & $\mathbf{1 3}$ & $\mathbf{2 . 0}$ \\
\hline $10^{\text {th }}$ grade EGB & 5 & 0.8 \\
\hline 1st grade BGU & 8 & 1.2 \\
\hline Total & $\mathbf{6 3 5}$ & $\mathbf{1 0 0}$ \\
\hline
\end{tabular}

As can be observed in Table 3, the results obtained through the pre-test showed that $70.9 \%$ of the students were placed in the A1 speaking proficiency level; while $15.6 \%$ were placed in the A2 proficiency level. In relation to the B1 and B1+ levels, only $11.5 \%$ and $2 \%$ of the students respectively were at these levels.

Table 4. Improvement of EFL learners' speaking proficiency

\begin{tabular}{|l|c|c|c|c|c|}
\hline School grades & \multicolumn{6}{|l|}{ Speaking proficiency levels } \\
\hline & $\mathbf{A 1}$ & $\mathbf{A 2}$ & $\mathbf{B 1}$ & $\mathbf{B 1 +}$ & Total \\
\hline Maintain proficiency level & $\mathbf{6 0 . 2}$ & $\mathbf{9 . 6}$ & $\mathbf{1 0 . 1}$ & $\mathbf{2 . 0}$ & $\mathbf{8 1 . 9}$ \\
\hline 10th grade of elementary school & 24.7 & 3.9 & 3.8 & 0.8 & 33.2 \\
\hline 1st grade of senior high school & 16.2 & 1.6 & 3.9 & 1.2 & 23.0 \\
\hline 2nd grade of senior high school & 19.2 & 4.1 & 2.4 & 0.0 & 25.7 \\
\hline Increase in proficiency level & $\mathbf{0 . 0}$ & $\mathbf{1 0 . 9}$ & $\mathbf{5 . 8}$ & $\mathbf{1 . 4}$ & $\mathbf{1 8 . 1}$ \\
\hline 10th grade of elementary school & 0.0 & 4.3 & 2.0 & 0.4 & 6.8 \\
\hline 1st grade of senior high school & 0.0 & 1.9 & 1.1 & 0.5 & 3.5 \\
\hline 2nd grade of senior high school & 0.0 & 4.4 & 2.7 & 0.5 & 7.9 \\
\hline Total & $\mathbf{6 0 . 2}$ & $\mathbf{2 0 . 5}$ & $\mathbf{1 5 . 9}$ & $\mathbf{3 . 4}$ & $\mathbf{1 0 0 . 0}$ \\
\hline
\end{tabular}

Table 4 presents the results obtained through the post-test application, which shows an improvement in the EFL learners' speaking proficiency. As it is observed, after carrying out the five workshops, $81.9 \%$ of the students who participated in this study maintained the same proficiency level that they had obtained in the pre-test; while $18.1 \%$ increased their speaking proficiency level. The results show that workshops, which help to develop critical thinking affect positively the improvement of EFL learners' speaking skills.

These results are similar to those obtained by Malmir and Shoorcheh (2012), who also found that students who had received instruction by using critical thinking strategies had better results on the oral interview post-test as opposed to the pretest.

Focusing specifically on students, who maintain the same speaking proficiency level, the results show that $60.2 \%$ are placed in the A1 level. Considering the high school grade, we have that $24.7 \%$ of the students belong to the 10 th grade of elementary school, followed by the 2 nd grade of senior high school $(19.2 \%)$ and the 1st grade of senior high school (16.2\%). In addition, $10.1 \%$ of students maintained the B1 level; and they correspond to the following high school grades: 1 st grade of senior high school (3.9\%), 10th grade of elementary school $(3.8 \%)$ and the 2 nd grade of senior high school (2.4). 
Similarly, $9.6 \%$ of the students maintained the A2 level. These students belong to the 2nd grade of senior high school (4.1\%), 10th grade of elementary school (3.9\%) and 1st grade of senior high school (1.6\%). Regarding level B1+, only $2 \%$ of the students maintain this level, $1.2 \%$ correspond to 1st grade of senior high school and $0.8 \%$ correspond to 10 th grade of elementary school.

According to the results, it is evident that even though students did not reach a higher speaking proficiency level after participating in the workshops, they strengthened their knowledge at the level they placed in the pre-test. For example, in the pre-test, some students did not answer correctly all the questions related to levels A1, A2, B1, and B1+; but in the post-test, in some cases, most of them used more vocabulary expressions in their responses and they also expressed their ideas on properly using the correct grammar rules

In this study, one major explanation for these findings is that during the workshops, the students participated in more interactive activities, such as communication games and role-plays. These activities are part of intrinsically motivating techniques, which according to Brown and Lee (2015), help to appeal to students' ultimate goals, interests, need for knowledge, and for achieving competence and autonomy. The data also suggest that the use of critical thinking activities had a positive impact on students' attitudes, similar to that of Changwon et al. (2018), who concluded in their study that students showed gratification with the use of activities that facilitated learning. During the observations, it was found that students showed good predisposition and strong interests in participating. In addition, they were highly engaged in the speaking activities.

In relation to the results obtained from the students, who increased their proficiency level, it could be observed that $10.9 \%$ of them, who were in A1, reached the A2 level. Most of these students belonged to the 2nd grade of senior high school with $4.4 \%$ followed by the $10^{\text {th }}$ grade of elementary school, with $4.3 \%$ and 1 st- grade BGU with $1.9 \% .5 .8 \%$ of the participants who were in A2 reached the B1 level. These students correspond to the 2nd grade of senior high school, and the 10th grade of elementary school and the 1st grade of senior high school $(2.7 \%, 2 \%, 11 \%$ correspondingly).

Finally, 1.4\% of the students who were placed in B1 reached the B1+ level. These students belonged to the 1st grade of senior high school and the 2nd grade of senior high school $(0.5 \%$ each) and the 10 th grade of elementary school with $0.4 \%$.

The results demonstrate that only $18.1 \%$ of the students increased their oral proficiency level. Although this percentage is low; and it does not represent all the students, it is a good result, because of the number of workshops who applied. It reveals that getting students involved in similar critical-thinking workshops focused on role-playing, short stories, and communication games will frequently render them to successfully improve their speaking skills. In this regard, the results provided by Changwon et al. (2018) demonstrate that each student benefits from the critical-thinking activities applied during instruction. Students can solve problems effectively; and this develops their self-confidence (lves). 
Therefore, we may conclude that critical thinking training impacts the improvement of speaking skills. It has been found that students improve their speaking skills when they carry out activities that require them to think critically (Kaviani and Mashhadi, 2020).

Based on the results obtained from the three school grades, the 2nd grade of senior high school presented the highest percentage of students $(7.9 \%)$, who had improved their level of speaking skills. Most of them, who had been placed in A1 in the pre-test, changed to A2 (4.4\%).

Moreover, the workshops conducted for the students of the 1st grade of senior high school and the 2nd grade of senior high school had a positive impact on the improvement of students' speaking skills. Based on these observations carried out by the university lecturers, this improvement is the result of giving equal opportunities to all the students to participate during the workshops. In addition, pre-service teachers applied appropriate classroom materials, based on the students' age and level.

They provided clear instructions and supported their learning through teaching activities, such as educational games, pictures, communication games, role-plays, and short stories. The workshops increased critical thinking and improved students' speaking skills; since they had sufficient opportunities to interact with their classmates, to analyze information, to convey ideas, to solve problems, and to make conclusions. It is important to emphasise that the improvement showed by students during the last workshop focused on a role-playing activity that was recorded as evidence of progress.

Table 5. ANOVA Statistics analysis of the post-test results

\begin{tabular}{|l|c|c|c|c|c|}
\hline \multicolumn{1}{|c|}{ School grades } & $\begin{array}{c}\text { Sum of } \\
\text { squares }\end{array}$ & gl & $\begin{array}{c}\text { Root mean } \\
\text { square }\end{array}$ & F & Sig. \\
\hline Among groups & 1,851 & 3 & 0,617 & 0,842 & 0,471 \\
\hline Inside groups & 462,502 & 631 & 0,733 & & \\
\hline Total & $\mathbf{4 6 4 , 3 5 3}$ & $\mathbf{6 3 4}$ & & & \\
\hline
\end{tabular}

Table 5 shows that the statistical significance of the obtained results is 0,471 , which is higher than the standard significance level (0.05). This statistically demonstrates that the implementation of critical thinking activities helps to improve students' speaking skills.

Table 6. ANOVA Statistics analysis of the post-test results considering gender

\begin{tabular}{|l|r|r|r|r|r|}
\hline Students'gender & $\begin{array}{c}\text { Sum of } \\
\text { squares }\end{array}$ & gl & $\begin{array}{c}\text { Root mean } \\
\text { square }\end{array}$ & F & \multicolumn{1}{c|}{ Sig. } \\
\hline Among groups & 0,256 & 3 & 0,085 & 0,341 & 0,796 \\
\hline Inside groups & 157,697 & 631 & 0,250 & & \\
\hline Total & $\mathbf{1 5 7 , 9 5 3}$ & $\mathbf{6 3 4}$ & & & \\
\hline
\end{tabular}


Table 6 shows that the results vary, depending on gender. The statistical significance is 0,796 , in which the females got better results than the males.

\section{Conclusion}

The findings demonstrate that critical-thinking workshops have a positive impact on the improvement of students' speaking skills; since they allow them to put into practice the English language by promoting interaction and creativity. Allowing students to create dialogues or stories in activities, such as role-plays, storytelling, or communication games more frequently provides valuable opportunities to make them think critically, to analyze information, to solve problems, to convey ideas, and to draw conclusions. The improvement of the students' speaking proficiency level obtained after the intervention is clear evidence of the advantages of using these activities.

Additionally, the previously mentioned activities provide opportunities to improve grammar, vocabulary, pronunciation, and fluency, which are important linguistic aspects that need to be reinforced, in order to make students feel confident when using the language orally. This confidence increases students' oral participation in class, which is very necessary, in order to help them to improve their speaking proficiency level; because the more they use the language in class, the more readily will they learn it. It is important to mention that a positive impact was also noticed regarding students' attitudes. Hence, the importance of learning more about strategies for critical thinking development to be applied in the English teaching-learning process; providing thereby, the proper material to students, which would also contribute to the improvement of their speaking skills.

\section{Suggestions for further research}

Despite the positive findings of this study, it is suggested to increase the number of workshops and cover additional instructional strategies, in order to give students more opportunities to obtain better academic results. Also, as this study mainly focused on adolescents, further research on children should be appropriate to help them to become involved at an early stage in critical-thinking activities that enhance their oral communication in English.

\section{Acknowledgement}

The authors of this research show special gratitude to Universidad Técnica Particular de Loja for their support in the research field and the EFL Learning, Teaching, and Technology Research Group.

\section{References}

Altun, M. (2015). Using role-play activities to develop speaking skills: A case study in the language classroom. International Journal of Social Sciences \& Educational Studies, 1(4), 27-33.

Akatsuka, Y. (2019). Awareness of critical thinking attitudes and English language skills: The effects of questions involving higher-order thinking. Journal of Pan-Pacific Association of Applied Linguistics, 23(2), 59-84. https://doi.org/10.25256/PAAL.23.2.4 
Anchalee, S. (2015). The use of debate technique to develop the speaking ability of grade ten students at Bodindecha (Sing Singhaseni) school. International Journal of Technical Research and Applications, (13), 27-31.

Arfae, A. (2019). The impact of teaching critical thinking on EFL learner' speaking skill: A case study of an Iranian context. English Language Teaching 13(1), https://doi.org/10.5539/elt.v13n1p112

Arias, G. (2017). Students' language skills development through short stories. Íkala, Revista de Lenguaje y Cultura, 22(1), 103-118. https://doi.org/10.17533/udea.ikala.v22n01a07

Brown, H., D., \& Lee, H. (2015). Teaching by principles: An interactive approach to language pedagogy. Pearson Education

Changwong, K., Sukkamart, A., \& Sisan, B. (2018). Critical thinking skill development: Analysis of a new learning management model for Thai high schools. Journal of International Studies, 11(2), 37-48. http://doi.org/10.14254/2071-8330.2018/11$2 / 3$

Cottrell, S. (2005). Critical Thinking Skills. Palgrave Macmillan

Dewi, R., Kultsum, U., \& Armadi, A. (2016). Using communicative games in improving students' speaking skills. English Language Teaching, 10(1), 63-71 http://dx.doi.org/10.5539/elt.v10n1p63

Facione, P. (2000). The disposition toward critical thinking: Its character, measurement, and relationship to critical thinking skills, 20(1), https://doi.org/10.22329/il.v20i1.2254

Gandimathi, A., \& Zarei, N. (2018). The impact of critical thinking on learning English language. Asian Journal of Social Science Research,

1(2). https://www.researchgate.net/publication/344487381_the_impact_of_criti cal_thinking_on_learning_the English_language

Gunada, W. (2017). Using YouTube videos: An IT-based media to improve students' speaking skills. https:// www.researchgate.net/publication/326082917

Harmer, J. (2015) The practice of English language teaching. Pearson Longman

Hernandez-Cherrez, E., Hidalgo-Camacho, C., \& Escobar, P. (2021). Communication games: Their contribution to developing speaking skills. International Journal of Instruction, 14(4), 643-658. https:/ / doi.org/10.29333/iji.2021.14437a

Hismanoglu, M., \& Colak, R. (2019). A Study on Turkish EFL Teachers' Perspectives on Using Drama to Develop Students' Speaking Skills in the EFL Classroom. Research on Youth and Language, 13(2), 187-205

Hwang, W. Y., Shadiev, R., Hsu, J. L., Huang, Y. M., Hsu, G. L., \& Lin, Y. C. (2016). Effects of storytelling to facilitate EFL speaking using Web-based multimedia system. Computer-Assisted Language Learning, 29(2), 215- 241. https://doi.org/10.1080/09588221.2014.927367

Iman, J. (2017). Debate instruction in EFL classroom: Impacts on the critical thinking and speaking skills. International Journal of Instruction, 10(4), 87-108. https://doi.org/10.12973/iji.2017.1046a

June, S., Yaacob, A., \& Kheng, Y. (2014) Assessing the use of YouTube videos and interactive activities as a critical thinking stimulator for tertiary students: An action research. International Education $\quad$ Studies, $\quad 7(8)$. http://dx.doi.org/10.5539/ies.v7n8p56

Kaiafa, E., Dima, A., \& Tsiaras A. (2020). The use of drama-education techniques in cultivating the critical thinking skills of students in primary schools. Journal of International Scientific Publications, 18, 139-148.

Kabooha, R., \& Elyas, T. (2015). The impacts of using YouTube videos on learning vocabulary in Saudi EFL classrooms. Paper presented at the ICERI2015 Conference. 
https://www.researchgate.net/profile/Raniah_Kabooha/ publication/2831535 82_the_impacts_of_using_youtube_videos_on_learning_vocabulary_in_Saudi_E FL_classroom/links/5843c13408ae2d2175638692/the-impacts-of-using-youtubevideos-on-learning-vocabulary-in-Saudi-EFL-classroom.pdf

Karsono, P. (2014). Using pictures in improving the speaking ability of the grade eight-A students of SMP Negeri 1 Anggana. Dinamika Ilmu, 14(2), 1-24.

Kaviani, M., \& Mashhadi Heidar, D. (2020). The Effectiveness of critical thinking on enhancing productive skills among Iranian EFL pre-intermediate learners. Applied Research on English Language, 9(3), 303-324.

Lau, J. (2011). An introduction to critical thinking and creativity: Think more, think better. John Wiley \& Sons, Inc.

Lavalle, P. \& Briesmaster, M. (2017). The study of the use of picture descriptions in enhancing communication skills among the 8th-grade students-learners of English as a foreign language. i.e.: Inquiry in education, 9(1), 1-18. http://digitalcommons.nl.edu/ie/vol9/iss1/4

Malmir, A., \& Shoorcheh, S. (2012). An investigation of the impact of teaching critical thinking on the Iranian EFL learners' speaking skills. Journal of Language Teaching and Research, 3(4), http:// doi.org/10.4304/jltr.3.4.608-617

Ministerio de Educación del Ecuador. (2016). Curriculum nacional lingua extranjera: English as a Foreign Language. https:/ / educacion.gob.ec/curriculo-lengua-extranjera/

Moseley, D., Baumfield, V., Elliott, J., Gregson, M., Higgins, S., Miller, J., \& Newton, D. P. (2005). Frameworks for thinking: A handbook for teaching and learning. Cambridge University Press.

Muhammadiyeva, H., Mahkamova, D., Valiyeva, Sh., \& Tojiboyev. I. (2020). The role of critical thinking in developing speaking skills. International Journal on Integrated Education, 3(1), 62 - 64. https://doi.org/10.31149/ijie.v3i1.41

Paul, R. (1985). Critical thinking: What every person needs to survive in a rapidly changing world. Foundation for Critical Thinking.

Pardede, P. (2011). Using short stories to teach language skills. Journal of English Teaching, $1(1), 14-27$.

Ramezani, R., Ezzati Larsari, E., \& Aghajanzadeh Kiasi, M. (2015). The relationship between critical thinking and EFL learners' speaking ability. English Language Teaching, 9(6), http://doi.org/10.5539/elt.v9n6p189

Sevy-Biloon, J. (2017). Different reasons to play games in an English language class. Journal of Education and Training Studies, 5(1), 84-93. http://dx.doi.org/10.11114/jets.v5il.1967

Snider, A., \& Schnurer, M. (2002). Many sides: Debate across the curriculum. New York: International Debate Education Association.

Vahdani, R., \& Tarighat, S. (2014). Critical thinking and speaking proficiency: A mixedmethod Study. Theory and Practice in Language Studies, 4(1), 79-87. http://doi.org/10.4304/tpls.4.1.79-87

Vellayan, G., Swaran, C. K., Tek, O. E., Yunus, M., Masa, T. S., \& Mulyadi, D. (2021). A review of studies on cooperative learning strategy to improve ESL students' speaking skills. Turkish Journal of Computer and Mathematics Education, 12(3), 6368, https://doi.org/10.17762/turcomat.v12i3.466

Villafuerte, J. (2019). Tecnología de la información y comunicación y el desarrollo de la competencia comunicativa en inglés de los futuros docentes de lengua extranjera de Ecuador: Propuesta de intervención educativa [Information and communication technology and the development of communicative competence in the English of future foreign language teachers in Ecuador: A proposal for educational intervention] [Thesis 
doctoral. Programa de Psicodidáctica y didácticas específicas, Universidad del País Vasco].

Worrell, J. A., \& Profetto-McGrath, J. (2007). Critical thinking as an outcome of contextbased learning among post RN students: A literature review. Nurse Education Today, 27, 420-426.

$\mathrm{Xu}, \mathrm{Q}$. (2013). Fostering critical thinking competence in EFL classroom. Studies in Literature and Language, 7(1), 6-9. http://dx.doi.org/10.3968/j.sll.1923156320130701.2717

Zare, P., \& Othman, M. (2015). Students' perceptions toward using classroom debate to develop critical thinking and oral communication ability. Asian Social Science, 11(9), https://doi.org/10.5539/ass.v11n9p158

Zuhriyah, M. (2017). Storytelling to improve students' speaking skill. English Education: Jurnal Tradis Bahasa Inggris, 10(1), 119-134. 


\section{Appendices}

STUDENTS' ORAL PRE-TEST

\begin{tabular}{|l|l|l|}
\hline Name of the institution: & \multicolumn{2}{|l|}{} \\
\hline Age of the student: & \multirow{2}{|l|}{} \\
\hline \multirow{2}{*}{ Gender: } & Female & \\
\cline { 2 - 3 } & Male & \\
\hline \multirow{2}{*}{ Grade: } & $10^{\text {th }}$ grade EGB & \\
\cline { 2 - 3 } & 1st grade BGU & \\
\cline { 2 - 3 } & 2nd grade BGU & \\
\hline City: & \multicolumn{2}{|l}{} \\
\hline
\end{tabular}

\begin{tabular}{|c|c|c|c|}
\hline \multicolumn{2}{|r|}{ Questions } & \multicolumn{2}{|c|}{ Level and lesson } \\
\hline & & \multirow{2}{*}{$\frac{\text { Beginner (B) }}{\text { B }}$} & \multirow{2}{*}{$\begin{array}{c}\text { Elementary (E) } \\
\text { E }\end{array}$} \\
\hline 1 & $\begin{array}{l}\text { What's your name? How do you spell } \\
\text { your surname? }\end{array}$ & & \\
\hline 2 & Where are you from? & B & $\mathbf{E}$ \\
\hline 3 & $\begin{array}{l}\text { Did you learn English at school? For } \\
\text { how many years? }\end{array}$ & B & E \\
\hline 4 & What do you do in your free time? & B & E \\
\hline 5 & $\begin{array}{l}\text { What do you do every day? What time } \\
\text { do you get up/go to high school? }\end{array}$ & B & E \\
\hline 6 & What did you do on your last vacation? & & E \\
\hline 7 & $\begin{array}{l}\text { Tell me something you could do well at } \\
\text { school. And something you can do well } \\
\text { now. }\end{array}$ & B & $\mathbf{E}$ \\
\hline 8 & $\begin{array}{l}\text { Tell me about the weather in the your } \\
\text { country. }\end{array}$ & & $\mathbf{E}$ \\
\hline 9 & $\begin{array}{l}\text { What are you going to do at the } \\
\text { weekend? }\end{array}$ & B & E \\
\hline 10 & $\begin{array}{l}\text { Have you been to an English-speaking } \\
\text { country (before)? }\end{array}$ & & $\mathbf{E}$ \\
\hline & & Pre-intermediate (PI) & Intermediate (I) \\
\hline 11 & $\begin{array}{l}\text { Let's talk about your friends. How } \\
\text { often do you normally see them? }\end{array}$ & PI & \\
\hline 12 & $\begin{array}{l}\text { Tell me about your best friend. What is } \\
\text { he or she like? }\end{array}$ & PI & \\
\hline
\end{tabular}




\begin{tabular}{|r|l|c|c|}
\hline $\mathbf{1 3}$ & $\begin{array}{l}\text { Let's talk about your house or home. } \\
\text { How would you describe it? }\end{array}$ & PI & I \\
\hline $\mathbf{1 4}$ & $\begin{array}{l}\text { How do you think your country/town } \\
\text { will change in the next 20 years? }\end{array}$ & $\mathbf{I}$ \\
\hline $\mathbf{1 5}$ & $\begin{array}{l}\text { What advice would you give to } \\
\text { someone visiting your country/town? }\end{array}$ & $\mathbf{I}$ \\
\hline $\mathbf{1 6}$ & $\begin{array}{l}\text { Tell me about the main news stories in } \\
\text { your country at the moment. }\end{array}$ & & \\
\hline
\end{tabular}

Taken from Cambridge University Press (2013). face2face: Oral Placement Test Questions. 


\section{OBSERVATION SHEET \\ WORKSHOP \#}

\section{A. INFORMATIVE DATA}

\begin{tabular}{|l|l|l|}
\hline Name of the institution: & \multicolumn{2}{|l|}{} \\
\hline Grade: & $10^{\text {th }}$ grade EGB & \\
\cline { 2 - 3 } & 1st grade BGU & \\
\cline { 2 - 3 } & 2nd grade BGU & \\
\hline City: & \multicolumn{2}{|c|}{} \\
\hline
\end{tabular}

\section{B. PLANNING}

\begin{tabular}{|l|l|l|l|}
\hline \multicolumn{1}{|c|}{ STATEMENTS } & YES & NO & COMMENTS \\
\hline $\begin{array}{l}\text { The objectives are clear, and they are related to } \\
\text { the improvement of the speaking skill through } \\
\text { the use of critical thinking activities. }\end{array}$ & & & \\
\hline The contents of the workshop are clearly & & & \\
stated. & & & \\
\hline The contents are related to the students' level & & & \\
and age. & & & \\
\hline The resources to be applied are described in & & & \\
\hline detail. & & & \\
\hline The critical thinking activities are presented in & & & \\
\hline The assessment procedure is stated. & & & \\
\hline
\end{tabular}

\section{DIDACTIC PROCEDURE}

\begin{tabular}{|c|c|c|c|}
\hline STATEMENTS & YES & NO & COMMENTS \\
\hline The topic of the workshop is clearly explained. & & & \\
\hline
\end{tabular}




\begin{tabular}{|l|l|l|l|}
\hline $\begin{array}{l}\text { The critical thinking activities are presented in } \\
\text { a logical sequence. }\end{array}$ & & & \\
\hline $\begin{array}{l}\text { The activities presented in the workshop } \\
\text { promote students critical thinking to improve } \\
\text { their speaking skills. }\end{array}$ & & & \\
\hline $\begin{array}{l}\text { The pre-service teacher is proficient in the } \\
\text { subject matter. }\end{array}$ & & & \\
\hline $\begin{array}{l}\text { Strategies such as short stories, educational } \\
\text { videos, games, pictures, and role-plays are }\end{array}$ & & & \\
used. & & & \\
\hline $\begin{array}{l}\text { The material is designed to support the } \\
\text { workshop development. }\end{array}$ & & & \\
\hline $\begin{array}{l}\text { Appropriate assessment techniques are } \\
\text { applied to monitor students' progress. }\end{array}$ & & & \\
\hline $\begin{array}{l}\text { Feedback is provided to reinforce } \\
\text { knowledge. }\end{array}$ & & & \\
\hline
\end{tabular}

\section{CLASSROOM ENVIRONMENT}

\begin{tabular}{|l|l|l|l|}
\hline \multicolumn{1}{|c|}{ STATEMENTS } & YES & NO & COMMENTS \\
\hline $\begin{array}{l}\text { Students have a positive attitude towards the } \\
\text { use of critical thinking activities. }\end{array}$ & & & \\
\hline $\begin{array}{l}\text { Students actively participate in each one of the } \\
\text { established activities. }\end{array}$ & & & \\
\hline $\begin{array}{l}\text { Students are highly motivated to participate in } \\
\text { the workshop. }\end{array}$ & & & \\
\hline Communication among students is promoted. & & & \\
\hline
\end{tabular}

